\title{
Effects of Temperature, Light and Seed Moisture Content on Germination of Euterpe precatoria Palm
}

\author{
Carla Rafaele Xavier Costa ${ }^{1}$, Kathia Fernandes Lopes Pivetta', \\ Gilberto Rostirolla Batista de Souza1, Renata Bachin Mazzini-Guedes², \\ Suzana Targanski Sajovic Pereira1, Marina Romano Nogueira1
}

${ }^{1}$ São Paulo State University-UNESP, Jaboticabal, Brazil

${ }^{2}$ Federal University of Paraná (UFPR), Jandaia do Sul, Brazil

Email:remazzini@yahoo.com.br

How to cite this paper: Costa, C.R.X., Pivetta, K.F.L., de Souza, G.R.B., Mazzini-Guedes, R.B., Pereira, S.T.S. and Nogueira, M.R. (2018) Effects of Temperature, Light and Seed Moisture Content on Germination of Euterpe precatoria Palm. American Journal of Plant Sciences, 9, 98-106.

https://doi.org/10.4236/ajps.2018.91009

Received: November 23, 2017

Accepted: January 16, 2018

Published: January 19, 2018

Copyright () 2018 by authors and Scientific Research Publishing Inc. This work is licensed under the Creative Commons Attribution International License (CC BY 4.0).

http://creativecommons.org/licenses/by/4.0/

\begin{abstract}
The aim of this study was to investigate the effects of different temperatures, light regimes, and seed moisture contents on germination of the palm Euterpe precatoria, in the Arecaceae family. For the study of light and temperature, the experimental design was entirely randomized; treatments were arranged in a $6 \times$ 2 factorial scheme [six temperature conditions $\left(20^{\circ} \mathrm{C}, 25^{\circ} \mathrm{C}, 30^{\circ} \mathrm{C}, 35^{\circ} \mathrm{C}, 20^{\circ} \mathrm{C}-\right.$ $30^{\circ} \mathrm{C}$, and $25^{\circ} \mathrm{C}-35^{\circ} \mathrm{C}$ ) combined with two light regimes (light and darkness)] with four replications composed of 25 seeds each. For the seed moisture content study, the experimental design was entirely randomized with five seed moisture contents $(27 \%, 20 \%, 13 \%, 12 \%$, and $11 \%)$, to which they comprised 5 treatments, and four replications with 25 seeds each. Number of germinated seeds was recorded daily until germination was steady. Data were submitted to variance analysis; for the first experiment, means were compared by the Tukey test $(\mathrm{p} \leq 0.05)$ and, for the second, the regression analysis was performed. The temperature at $20^{\circ} \mathrm{C}$ promoted highest germination percentage and germination rate for E. precatoria seeds, under either light or darkness; seeds were tolerant up to $11 \%$ moisture content.
\end{abstract}

\section{Keywords}

Arecaceae, Luminosity, Ornamental Palm, Seed Desiccation

\section{Introduction}

Euterpe precatoria Mart., in the family Arecaceae, is a single-stemmed palm occurring naturally in the Amazon region of Acre, Amazonas, Pará, and Rondônia 
states, Brazil, measuring from 3 to $20 \mathrm{~m}$ height [1]. Commonly known as Amazonian açaí or mountain cabbage, it shows great economic potential mainly because of its fruits. A thick liquid, called "açaí wine", is extracted from the fresh edible mesocarp, which is the most used part. Such beverage is largely consumed by the entire population from the Brazilian Amazon [2]. Furthermore, the açaí juice of $E$. precatoria presents potential as a source of energy, lipids, dietary fiber, anthocyanins, monounsaturated fatty acids, and minerals [3]. The palm is also used for the extraction of heart of palm and timber.

In general, palm seed germination is slow and uneven, usually resulting in low seedling stand. Its propagation is made almost exclusively from seeds with a great variation on the germination process that, also, is influenced by several factors [4] [5], such as temperature, light, and moisture.

The temperature at germination influences, for instance, the speed of water absorption by seeds and may change, among others, the total germination percentage, rate, and uniformity [6]. For germination of palm seeds, temperatures considered appropriate vary from $20^{\circ} \mathrm{C}$ to $40^{\circ} \mathrm{C}$, but best results are obtained from $30^{\circ} \mathrm{C}$ to $35^{\circ} \mathrm{C}$ for most species [5]. Furthermore, seeds of many species germinate better when submitted to the range of $25^{\circ} \mathrm{C}$ to $35^{\circ} \mathrm{C}$ [4].

For some ecological groups, light presence may affect seed germination [6]. However, seed sensitivity to light is highly variable and specific, so seeds may be either positively or negatively influenced and, yet, indifferent [7].

Many plant species produce seeds that lose viability according to dehydration [8], so tolerance to low seed moisture contents also varies among species [9].

Our objective was to verify the effects of different temperatures, light regimes, and seed moisture contents on germination of the palm Euterpe precatoria.

\section{Materials and Methods}

Two experiments were conducted to study: 1) the effects of temperature and light on seed germination of E. precatoria; and 2) the effects of seed moisture contents on germination of E. precatoria. Both were implemented in the Laboratory of Seed Analysis belonging to the Department of Crop Production at the College of Agricultural and Veterinary Sciences of the São Paulo State University-UNESP, located in the municipality of Jaboticabal, Brazil $\left(21^{\circ} 15^{\prime} 22^{\prime \prime S}\right.$ and $48^{\circ} 18^{\prime} 58^{\prime \prime} \mathrm{W}$, at $590 \mathrm{~m}$ altitude).

Fruits were harvested from native palms naturally growing in the municipality of Humaitá, Amazonas State, Brazil $\left(07^{\circ} 30^{\prime} 22^{\prime \prime S}\right.$ and $63^{\circ} 01^{\prime} 38^{\prime \prime} \mathrm{W}$, at $59 \mathrm{~m}$ altitude). According to the Köppen classification, the climate regime in Humaitá is of Am type-tropical monsoon, or tropical wet climate, with wet and dry seasons and steady temperatures along the year. After harvest, fruits were packed in plastic bags with vermiculite of medium texture and transported to Jaboticabal.

In the lab, fruits were kept in water for 24 hours to ease pulp removal and then epicarp and mesocarp were removed by manual friction against a steel mesh sieve. Seed initial moisture content (botanically, a pyrene) was determined 
gravimetrically by oven drying for 24 hours at $105^{\circ} \mathrm{C} \pm 3^{\circ} \mathrm{C}$ [10], using two samples of 10 seeds each.

For the study of temperature and light effects, the experimental design was entirely randomized. Treatments were arranged in a $6 \times 2$ factorial scheme [six temperature conditions (constant at $20^{\circ} \mathrm{C}, 25^{\circ} \mathrm{C}, 30^{\circ} \mathrm{C}$, and $35^{\circ} \mathrm{C}$, and alternated at $20^{\circ} \mathrm{C}-30^{\circ} \mathrm{C}$ and $25^{\circ} \mathrm{C}-35^{\circ} \mathrm{C}$ ) combined with two light regimes (light and darkness)] with four replications of 25 seeds each.

Seeds were placed in transparent plastic boxes $(11 \times 11 \times 3 \mathrm{~cm})$ for the light treatment, or in black ones for the darkness treatment, which were filled with vermiculite of medium texture kept at $100 \%$ of its water retention capacity, previously studied by the gravimetric method. The plastic boxes were then packed in transparent plastic bags. The photoperiod, for the light treatment, was of $16 \mathrm{~h}$ light in a germination chamber.

For the study of seed moisture contents, the experimental design was entirely randomized, with five treatments composed of different seed moisture contents $(27 \%, 20 \%, 13 \%, 12 \%$, and $11 \%)$ and four replications of 25 seeds each.

Treatments were established according to the seed moisture content [10]. Thus, the first treatment was the initial seed moisture content (27\%), while the others were determined every three days after diaspore drying at room temperature; therefore, the last treatment was obtained after 12 days of drying.

Seeds were placed in transparent plastic boxes $(11 \times 11 \times 3 \mathrm{~cm})$ filled with vermiculite of medium texture kept at $100 \%$ of its water retention capacity, previously studied by the gravimetric method. The plastic boxes were then placed in a germination chamber at $30^{\circ} \mathrm{C}$.

Seeds of both experiments were considered germinated when seedlings first appeared. Numbers of germinated seeds were noted daily, always at the same time, until germination was steady.

Data were submitted to the variance analysis. For the temperature and light experiment, means were compared by the Tukey test ( $p \leq 0.05)$; for the seed moisture content experiment, the polynomial regression was performed to verify variable behavior (germination percentage and germination rate) due to decreasing moisture content, defining the best adjustment according to the combination of significance and highest determination coefficient. Data of germination rate was calculated as

$$
\mathrm{GR}=\mathrm{N} 1 / \mathrm{D} 1+\mathrm{N} 2 / \mathrm{D} 2+\cdots+\mathrm{Nn} / \mathrm{Dn},
$$

where GR is the germination rate, $\mathrm{N}$ is the number of normal seedlings noted from the first to the last counting, and $\mathrm{D}$ is the number of days from the first to the last counting [11]. Data of germination percentage were transformed into arcsine $(\mathrm{x} / 100)^{1 / 2}$ for normalization.

\section{Results}

There was an interaction among temperatures and light regimes for both germination percentage and germination rate; when seeds were submitted to light, 
there was no difference among temperatures, with the exception of the constant temperature at $35^{\circ} \mathrm{C}$, which promoted the lowest values. Under darkness, higher germination percentages were obtained under the constant temperatures at 20 and $25^{\circ} \mathrm{C}$, and the alternated at $20^{\circ} \mathrm{C}-30^{\circ} \mathrm{C}$ (Table 1 ).

Regarding the germination rate, seeds germinated faster when submitted to light, at $20^{\circ} \mathrm{C}$; in turn, the latter did not differ from the constant temperature at $25^{\circ} \mathrm{C}$, and alternated at $20^{\circ} \mathrm{C}-30^{\circ} \mathrm{C}$ and $25^{\circ} \mathrm{C}-35^{\circ} \mathrm{C}$. Under darkness, $20^{\circ} \mathrm{C}$ was also the temperature that promoted the highest means (Table 1).

The temperature at $20^{\circ} \mathrm{C}$ promoted highest means of both germination percentage and germination rate, under light or darkness; on the other hand, the $35^{\circ} \mathrm{C}$ treatment resulted in the lowest means regardless light presence (Table 1).

Regarding seed tolerance to low moisture contents, both germination percentage and germination rate decreased according to reduced seed moisture content (Figure 1). Therefore, high germination percentage was obtained immediately after harvest. However, even with decreasing germination according to moisture loss, germination was high, of about $95 \%, 89 \%, 84 \%, 83 \%$, and $69 \%$ for seed moisture contents of, respectively, 27 (at harvest), 20\%, 13\%, 12\%, and $11 \%$.

\section{Discussion}

Germination, in general, was favored by lower temperatures, both in the light or darkness, even being E. precatoria a native species from a tropical region, as such condition is associated with its occurrence in lowland tropical forests, i.e., humid and dense locations, and sites at $600 \mathrm{~m}$ altitude [1]. However, when seeds were submitted to light, both germination percentage and germination rate were higher under a larger temperature range, similar to what happens to species growing in dry lands. On the contrary, the alternated temperature at $26^{\circ} \mathrm{C}-40^{\circ} \mathrm{C}$ was the most favorable for seed germination of Bactris maraja, another palm species that naturally occurs in the same region as E. precatoria [12].

Table 1. Germination percentage (\%) and germination rate of Euterpe precatoria seeds submitted to light or darkness at different temperature conditions.

\begin{tabular}{|c|c|c|c|c|c|c|c|c|}
\hline \multirow{3}{*}{$\begin{array}{c}\text { Temperature } \\
20^{\circ} \mathrm{C}\end{array}$} & \multicolumn{4}{|c|}{ Germination (\%) } & \multicolumn{4}{|c|}{ Germination Rate } \\
\hline & \multicolumn{2}{|l|}{ Light } & \multicolumn{2}{|l|}{ Darkness } & \multicolumn{2}{|c|}{ Light } & \multicolumn{2}{|c|}{ Darkness } \\
\hline & $78.90^{\mathrm{a}}(96.29)^{\mathrm{b}}$ & $\mathrm{aA}$ & $78.34^{\mathrm{a}}(95.92)^{\mathrm{b}}$ & $\mathrm{aA}$ & 1.616 & $\mathrm{aB}$ & 2.054 & $\mathrm{aA}$ \\
\hline $25^{\circ} \mathrm{C}$ & $79.16(96.46)$ & $\mathrm{aA}$ & $76.77(94.76)$ & $\mathrm{aA}$ & 1.424 & $\mathrm{abA}$ & 1.075 & bB \\
\hline $30^{\circ} \mathrm{C}$ & $75.14(93.42)$ & $\mathrm{aA}$ & $34.87(32.69)$ & $\mathrm{bB}$ & 1.145 & $\mathrm{bA}$ & 0.319 & $\mathrm{~dB}$ \\
\hline $35^{\circ} \mathrm{C}$ & $13.01(5.06)$ & bA & $2.88(0.25)$ & $\mathrm{cA}$ & 0.070 & $\mathrm{cA}$ & 0.036 & $\mathrm{dA}$ \\
\hline $20^{\circ} \mathrm{C}-30^{\circ} \mathrm{C}$ & $81.35(97.74)$ & $\mathrm{aA}$ & $62.27(78.35)$ & $\mathrm{aB}$ & 1.537 & $\mathrm{abA}$ & 0.793 & $\mathrm{bcB}$ \\
\hline $25^{\circ} \mathrm{C}-35^{\circ} \mathrm{C}$ & $71.22(89.64)$ & $\mathrm{aA}$ & $42.02(44.81)$ & $\mathrm{bB}$ & 1.238 & $\mathrm{abA}$ & 0.408 & $\mathrm{cdB}$ \\
\hline CV (\%) & \multicolumn{4}{|c|}{14.86} & \multicolumn{4}{|c|}{20.27} \\
\hline
\end{tabular}

${ }^{a}$ Data transformed into arcsine $(\mathrm{x} / 100)^{1 / 2}$. ${ }^{b}$ Nontransformed data. Means followed by the same lower case letters in the column and upper case letters in the line do not differ from each other by the Tukey test at $5 \%$ probability. 

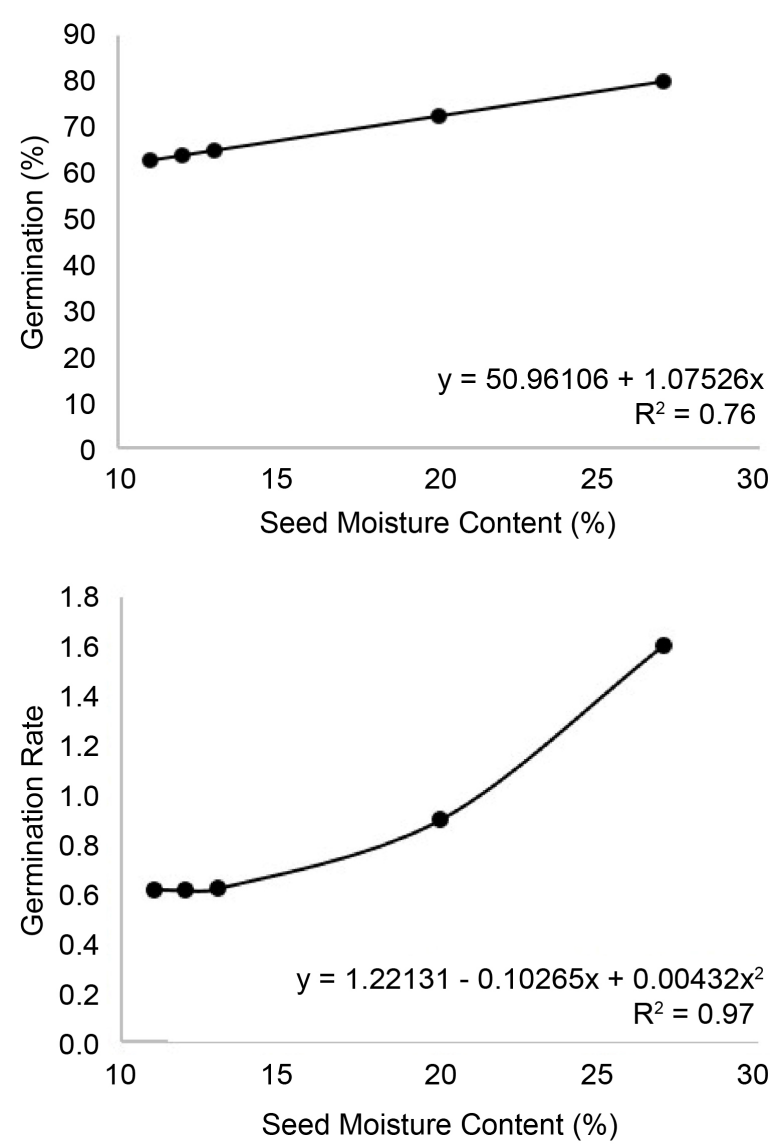

Figure 1. Germination percentage (\%) [data transformed into arcsine $(\mathrm{x} / 100)^{1 / 2}$ ] and germination rate of Euterpe precatoria according to different seed moisture contents.

Most palms are of tropical origin, with seeds that germinate under higher temperatures. Thus, there are several studies indicating that temperatures falling between $20^{\circ} \mathrm{C}$ and $40^{\circ} \mathrm{C}$ are considered generally acceptable for palm seed germination [5]. However, we did not find research results that show higher palm seed germination at $20^{\circ} \mathrm{C}$; in fact, such temperature seems to limit germination of some species. For instance, it negatively affects, or completely inhibits, germination of Syagrus romanzoffiana [13] and Archontophoenix cunninghamii [14]. From a temperature increase to $25^{\circ} \mathrm{C}$, best results are observed for Rhapis excelsa [15], Phoenix roebelenii [16], and Copernicia prunifera [17].

It is not possible, therefore, to indicate a general optimum germination temperature for all palms [18], as each genus, or even species, seems to require specific germination environmental conditions according to seed physical and physiological characteristics. The endocarp of Acrocomia aculeata seeds, for instance, may act on the seed tolerance to high temperatures, what is an important survival strategy in its natural habitat [19]. This may also happen with E. precatoria that showed lowest germination under $35^{\circ} \mathrm{C}$, as mean annual temperatures where seeds were harvested fall around $26^{\circ} \mathrm{C}$.

About light presence, our results showed that it is not necessary for seed ger- 
mination of E. precatoria, similarly to what was described for other palms, such as Aiphanes aculeata [20], Rhapis excelsa [15], and Livistona chinensis [21]. Furthermore, the dependence of palm seed germination on light is not known [4].

Regarding seed tolerance to low moisture contents, germination percentage of E. precatoria was high, above $69 \%$ regardless drying (up to $11 \%$ moisture content), i.e., critical and lethal moisture contents were not observed for this species. Such critical and lethal moisture contents do vary according to the species, but are generally considered high when fall around, respectively, 27\% and 38\% [22] [23] [24] [25], and $12 \%$ and 22\% [23] [25] [26] [27]. Additionally, knowledge on seed critical and lethal moisture contents is essential for seed conservation during drying and storage [28].

Although seed germination percentage and germination rate have decreased with moisture loss, E. precatoria seeds were considered tolerant to low moisture contents. Such tolerance capacity is clearly beneficial as it allows seed persistence for long periods through time in relatively arid environments [29].

Considering the seed classification in orthodox, recalcitrant, and intermediate, the behavior is considered intermediate when seeds survive under moderate drying, generally, up to $12 \%$ moisture content [30]; such seeds may then be stored for a longer period in comparison with recalcitrant ones. As most palm seeds are recalcitrant, seed viability is reduced when the moisture content reaches lower values than those considered critical; when such values are equal or lower than lethal ones, there is total viability loss [28] [31] [32] [33].

Critical and lethal seed moisture contents were already indicated for some palm species, such as Euterpe espiritosantensis ( $40.7 \%$ to $51.4 \%$ and $13.4 \%$ to $15.8 \%$, respectively) [28], Euterpe oleracea (34.2\% to $36.4 \%$ and $17.4 \%$ to $18.9 \%$, respectively) [34], and Bactris gasipaes (23.0\% to $28.0 \%$ and $13.9 \%$ to $15.0 \%$, respectively) [35]. However, for B. gasipaes, seeds also presented tolerance and lethal levels of $30.0 \%$ and $12.0 \%$, respectively [36]; on the other hand, for seeds submitted to lowermoisture contents than $38.0 \%$, germination and vigor were rapidly reduced, while $17 \%$ moisture content, or lower, promoted a very poor germination [23]. Furthermore, drying did reduce seed germination and vigor of Bactris maraja palm when seed moisture content decreased from $23.6 \%$ to $7.8 \%$ along 15 days [12], while seeds of Carpentaria acuminata and Phoenix canariensis tolerated drying at $5 \%$ and $8 \%$ seed moisture, respectively [37]. On the other hand, seeds of Dypsis decaryi and Ptychosperma elegans were sensitive to dehydration even at high moisture contents, $20 \%$ and $27 \%$, respectively [37].

\section{Conclusion}

For Euterpe precatoria seeds, the temperature at $20^{\circ} \mathrm{C}$ promoted highest means of germination percentage and germination rate, under either light or darkness. Seeds were tolerant up to $11 \%$ moisture content.

\section{Acknowledgements}

To the Research Support Foundation of Amazonas State (FAPEAM) for finan- 
cial support to this research (RH-Interiorization-Continuous Flow-Notice 003/2015-IV Call); and to the National Council of Technological and Scientific Development $(\mathrm{CNPq})$ for the financial support to this research (Process 484299/2013-1) and a research productivity grant to the second author (Process 308086/2012-0).

\section{References}

[1] Henderson, A. (2000) The Genus Euterpe in Brazil. In: Reis, M.S. and Reis, A., Eds., Euterpe edulis Martius (Palmiteiro)-Biologia, Conservação e Manejo, Herbário Barbosa Rodrigues, Itajaí, 1-22.

[2] Castro, A. (1992) O Extrativismo do Açaí no Amazonas. In: Relatório de Resultados do Projeto de Pesquisa: Extrativismo na Amazônia Central, Viabilidade e Desenvolvimento. INPA-CNPq/ORSTOM, Manaus, 779-782.

[3] Yuyama, L.K.O., Aguiar, J.P.L., Silva Filho, D.F., Yuyama, K., Varejão, M.J., Fávaro, D.I.T., Vasconcellos, M.B.A., Pimentel, S.A. and Caruso, M.S.F. (2011) Caracterização Físico-química do Suco de Açaí de Euterpe precatoria Mart. Oriundo de Diferentes Ecossistemas Amazônicos. Acta Amazonica, 41, 545-552. https://doi.org/10.1590/S0044-59672011000400011

[4] Broschat, T.K. (1994) Palm Seed Propagation. Acta Horticulturae, 360, 141-147. https://doi.org/10.17660/ActaHortic.1994.360.18

[5] Meerow, A.W. (1991) Palm Seed Germination. Cooperative Extension Service, Florida.

[6] Castro, R.D. and Hilhorst, H.W.M. (2004) Embebição e Reativação do Metabolismo. In: Ferreira, A.G. and Borghetti, F., Eds., Germinação: Do Básico ao Aplicado, Artmed, Porto Alegre, 149-162.

[7] Borges, E.E.L. and Rena, A.B. (1993) Germinação de Sementes. In: Aguiar, I.B., Piña-Rodrigues, F.C.M. and Figliolia, M.B., Eds., Sementes Florestais Tropicais, Abrates, Brasília, 83-135.

[8] Farnsworth, E. (2000) The Ecology and Physiology of Viviparous and Recalcitrant Seeds. Annual Review of Ecology and Systematics, 31, 107-138.

https://doi.org/10.1146/annurev.ecolsys.31.1.107

[9] Berjak, P. and Pammenter, N.W. (2008) From Avicennia to Zizania: Seed Recalcitrance in Perspective. Annals of Botany, 101, 213-228. https://doi.org/10.1093/aob/mcm168

[10] Brasil, Ministério da Agricultura, Pecuária e Abastecimento (2009) Regras para Análise de Sementes. Secretaria de Defesa Agropecuária, Brasília.

[11] Maguire, J.D. (1962) Speed of Germination-Aid in Selection and Evaluation for Seedling Emergence and Vigor. Crop Science, 2, 176-177. https://doi.org/10.2135/cropsci1962.0011183X000200020033x

[12] Rodrigues, J.K., Mendonça, M.S. and Gentil, D.F.O. (2014) Efeito da Temperatura, Extração e Embebição de Sementes na Germinação de Bactris maraja Mart. (Arecaceae). Revista Árvore, 38, 857-865. https://doi.org/10.1590/S0100-67622014000500010

[13] Pivetta, K.F.L., Paula, R.C., Cintra, G.S., Pedrinho, D.R., Casali, L.P., Pizetta, P.U.C. and Pimenta, R.S. (2005) Effects of Temperature on Seed Germination of Queen Palm Syagrus romanzoffiana (Cham.) Glassman. Acta Horticulturae, 683, 379-381. https://doi.org/10.17660/ActaHortic.2005.683.49 
[14] Pivetta, K.F.L., Sarzi, I., Estellita, M. and Beckmann-Cavalcante, M.Z. (2008) Tamanho do Diásporo, Substrato e Temperatura na Germinação de Sementes de Archontophoenix cunninghamii (Arecaceae). Revista de Biologia e Ciências da Terra, 8, 126-134.

[15] Aguiar, F.F.A., Bilia, D.A.C., Kanashiro, S., Tavares, A.R. and Barbedo, C.J. (2005) Germinação de Sementes de Rhapis excelsa (Thunb.) Henry ex Rehder: Efeitos da Temperatura, Luz e Substrato. Hoehnea, 32, 119-126.

[16] Iossi, E., Sader, R., Pivetta, K.F.L. and Barbosa, J.C. (2003) Efeitos de Substratos e Temperaturas na Germinação de Sementes de Tamareira-anã (Phoenix roebelenii O'Brien). Revista Brasileira de Sementes, 25, 63-69. https://doi.org/10.1590/S0101-31222003000400009

[17] Reis, R.G.E., Bezerra, A.M.E., Gonçalves, N.R., Pereira, M.S. and Freitas, J.B.S. (2010) Biometria e Efeito da Temperatura e Tamanho das Sementes na Protrusão do Pecíolo Cotiledonar de Carnaúba. Ciência Agronômica, 41, 81-86.

[18] Pivetta, K.F.L., Pedrinho, D.R., Batista, G.S., Gimenes, R. and Beckmann-Cavalcante, M.Z. (2013) Seed Germination of Two Syagrus Species Native to Brazil. Acta Horticulturae, 1000, 373-376. https://doi.org/10.17660/ActaHortic.2013.1000.51

[19] Rodrigues-Junior, A.G., Oliveira, T.G.S, Souza, P.P. and Ribeiro, L.M. (2016) Temperature Effects on Acrocomiaaculeata Seeds Provide Insights into Overcoming Dormancy in Neotropical Savanna Palms. Flora, 223, 30-37.

https://doi.org/10.1016/j.flora.2016.04.011

[20] Silva, M.A.S., Castellani, E.D. and Demattê, M.E.S.P. (1999) Effect of Fruit Maturation Stage and Light on Seed Germination of Aiphanesaculeata. Acta Horticulturae, 86, 229-234. https://doi.org/10.17660/ActaHortic.1999.486.34

[21] Kobori, N.N., Pivetta, K.F.L., Demattê, M.E.S.P, Silva, B.M.S., Luz, P.B. and Pimenta, R.S. (2009) Efeito da Temperatura e do Regime de Luz na Germinação de Sementes de Palmeira-leque-da-China (Livistona chinensis (Jack.) R. Br. ex. Mart.). Revista Brasileira de Horticultura Ornamental, 15, 29-35.

[22] Chin, H.F. (1988) Recalcitrant Seeds: A Status Report. International Board for Plant Genetic Resources, Wageningen.

[23] Ferreira, S.A.N. and Santos, L.A. (1992) Viabilidade de Sementes de Pupunha (Bactris gasipaes Kunth.). Acta Amazonica, 22, 303-307. https://doi.org/10.1590/1809-43921992223307

[24] Eira, M.T.S., Salomão, A.N., Cunha, R. Carrara, D.K. and Mello, C.M.C. (1994) Efeito do Teor de Água sobre a Germinação de Sementes de Araucaria angustifolia (Bert.) O. Kuntze-Araucariaceae. Revista Brasileira de Sementes, 6, 71-75. https://doi.org/10.17801/0101-3122/rbs.v16n1p71-75

[25] Andrade, A.C.S. and Pereira, T.S. (1997) Comportamento de Armazenamento de Sementes de Palmiteiro (Euterpe edulis Mart.). Pesquisa Agropecuária Brasileira, 32, 987-991.

[26] Priestley, D.A. and Wiliams, S.E. (1985) Changes in Cotyledonary Lipids during Drying of Cocoa (Theobroma cacao L.) Seeds. Tropical Agriculture, 63, 65-67.

[27] Bovi, M.L.A. and Cardoso, M. (1978) Conservação de Sementes de Palmiteiro (Euterpe edulis Mart.). Bragantia, 37, 65-71. https://doi.org/10.1590/S0006-87051978000100027

[28] Martins, C.C., Nakagawa, J. and Bovi, M.L.A. (1999) Tolerância à Dessecação de Sementes de Palmito-vermelho (Euterpe espiritosantensis Fernandes). Revista Brasileira de Botânica, 2, 391-396. https://doi.org/10.1590/S0100-84041999000300007 
[29] Pammenter, N.W. and Berjak, P. (2000) Evolutionary and Ecological Aspects of Recalcitrant Seed Biology. Seed Science Research, 10, 301-306. https://doi.org/10.1017/S0960258500000349

[30] Seiffert, M., Alvarenga, A.A., Guimarães, R.M., Castro, E.M., Cardoso, M.G., Paiva, R., Dousseau, S. and Vieira, C.V. (2006) Efeito da Secagem e de Diferentes Temperaturas na Germinação de Sementes de Protium widgrenii Engler. Ciência e Agrotecnologia, 30, 35-42. https://doi.org/10.1590/S1413-70542006000100005

[31] Probert, R.J. and Longley, P.L. (1989) Recalcitrant Seed Storage Physiology in Three Aquatic Grasses (Zizaniapalustris, Spartinaanglica and Porteresiacoarctata). Annals of Botany, 63, 53-63. https://doi.org/10.1093/oxfordjournals.aob.a087728

[32] Pritchard, H.W. (1991) Water Potential and Embryonic Axis Viability in Recalcitrant Seeds of Quercusrubra. Annals of Botany, 67, 43-49.

https://doi.org/10.1093/oxfordjournals.aob.a088098

[33] Hong, T.D. and Ellis, R.H. (1992) Optimum Air-Dry Seed Storage Environments for Arabica Coffee. Seed Science and Technology, 20, 547-560.

[34] Martins, C.C., Nakagawa, J., Bovi, M.L.A. and Staguerlim, H. (1999) Teores de Água Crítico e Letal para Sementes de Açaí (Euterpe oleracea Mart.-Palmae). Revista Brasileira de Sementes, 21, 125-132.

https://doi.org/10.17801/0101-3122/rbs.v21n1p125-132

[35] Bovi, M.L.A., Martins, C.C. and Spiering, S.H. (2004) Desidratação de Sementes de Quatro Lotes de Pupunheira: Efeitos sobre a Germinação e o Vigor. Horticultura Brasileira, 22, 109-112. https://doi.org/10.1590/S0102-05362004000100023

[36] Carvalho, J.E.U. and Müller, C.H. (1998) Níveis de Tolerância e Letal de Umidade em Sementes de Pupunheira, Bactris gasipaes. Revista Brasileira de Fruticultura, 20, 283-289.

[37] Batista, G.S., Mazzini-Guedes, R.B., Pivetta, K.F.L., Pritchard, H.W. and Marks, T. (2016) Seed Desiccation and Salinity Tolerance of Palm Species Carpentaria acuminata, Dypsisdecaryi, Phoenix canariensis, and Ptychospermaelegans. Australian Journal of Crop Science, 10, 1630-1634. https://doi.org/10.21475/ajcs.2016.10.12.PNE204 